\title{
Ventilation mask adapted for endoscopy during the COVID-19 pandemic
}

\author{
(D) José Luiz Paccos ${ }^{1}$ \\ (D) Ivandro Paulo de Lima ${ }^{2}$ \\ Viviane Rissio Borba de Lima² \\ (iD) Natália Sayuri Mukai'
}

1. Médico do corpo clínico do Hospital Dr. Miguel Soeiro, Sorocaba, SP, Brasil. 2. Enfermeiro do corpo clínico do Hospital Dr. Miguel Soeiro, Sorocaba, SP, Brasil.

\section{SUMMARY}

In the context of the COVID-19 pandemic, endoscopy services must adopt preventive measures to maintain proper functioning due to a high risk of disease contagion. Triage protocols before and after the procedure, personal protective equipment, and environmental contamination control are some of the endoscopy society's recommendations. However, the risk of infection may remain high due to poor control over the source of contamination.

Using a combination of standardized supplies and accessories in a hospital, a ventilation mask adapted to be used in endoscopic procedures is proposed to reduce COVID-19 contamination.

KEYWORDS: Endoscopy. Endoscopy, Digestive System. Personal protective equipment. Respiratory protective devices. Coronavirus infections.

\section{INTRODUCTION}

During the period of the COVID-19 pandemic in Brasil, elective endoscopic examinations were suspended temporarily, being carried out only in cases of urgency and emergency ${ }^{1}$. Although this is not a commonly executed examination in COVID-19 cases, it is prudent to adopt precautionary measures for all patients, assuming that there are infected individuals who are asymptomatic, particularly in services that treat many cases of the disease ${ }^{2}$.

The routes of Sars-Cov-2 transmission include contact from person to person and contact with secretions or aerosols ${ }^{2}$. Endoscopic procedures expose professionals who are involved in all these contamination routes $^{3}$. The World Health Organization $(\mathrm{WHO})^{4}$ defines digestive endoscopy as a procedure with a potential to generate aerosols.

Several recommendations for endoscopy services suggest the control of infection transmission by preventing contact and cleaning up environments ${ }^{3,5,6}$. Thus, they propose, in addition to the screening of patients, the use of PPE and systematic disinfection of sites and surfaces. However, what happens during endoscopy is the protection of individuals present in the room, allowing the free dispersal of infectious material from the source (patient) $)^{3.7}$. Thus, there is some concern if we are really reducing the exposure of professionals and other patients at risk of contracting the infection. Studies show that viable virus particles 
may remain present in the air for up to three hours, and on surfaces, for up to three days ${ }^{8}$. Reducing the load of infective material that is released in the environment is, therefore, also a challenge.

\section{METHODS}

Assuming that any person can be infected, we propose a device to be used by the patient (blocking dispersing agents at the source). This device must, at the same time, act as a barrier, provide safe breathing, and allow the completion of the examination. We adapted an endoscopy mask that covers the airways of the patient, allowing them to breathe, coupled to a membrane filter that allows the passage of the endoscope through it (Figure 1). This set could be used for other procedures, such as transesophageal echocardiography and endoscopic retrograde cholangiopancreatography (ERCP).

\section{FIGURE 1}

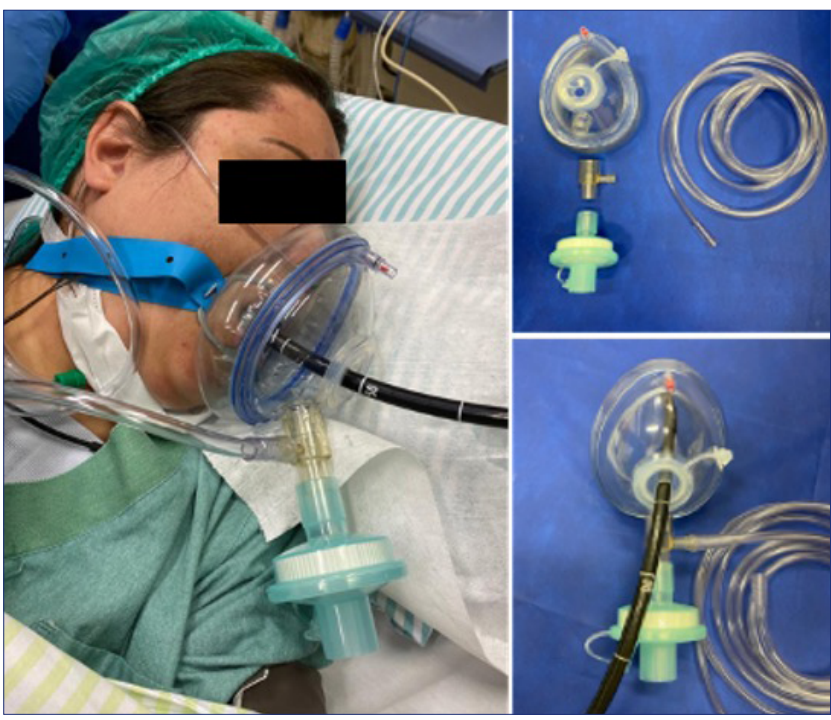

\section{DISCUSSION}

In order to carry out the endoscopy, the patient's mask is removed to access the digestive tract. Similarly to what happens during orotracheal intubation, aerosols are released in the environment is, especially during the passage of the device through the cricopharynx, when the reactivity of the airways can occur and, consequently, cough ${ }^{3}$. At that moment, infectious particles can be released up to 2 or 3 meters away, reaching the space where doctors and assistants are positioned ${ }^{3,9,10}$. Another consideration is the direction of the spray of infectious particles towards the endoscopist due to the position of the patient, i.e., lateral decubitus with their face turned to the assistants. In addition, the mouthpiece and endoscopy device form a barrier to expiration; this increases the angle of aerosol dispersion and, similarly to what occurs in the presence of a tracheal tube and the hand of the doctor positioned opposite to the mouth of the patient, exhaled air spreads widely ${ }^{2}$. Thus, the use of masks and other barrier devices can reduce the distance of dispersion of infectious agents when worn by the patient ${ }^{11}$. A similar modified ventilation mask has already been proposed in another health service ${ }^{12}$. The great advantage of using this mask is that it requires existing and available material, in addition to its ease of use.

\section{CONCLUSION}

Although there are no scientific studies that confirm the effectiveness of this mask, we justify its use as a way to strengthen the protective barrier against COVID-19, in addition to other protective equipment already being used (impermeable aprons, goggles, among others).

\section{Conflict of interest}

The authors have no conflicts of interest (professional or financial and no direct or indirect benefits) that might influence or have influenced the research results or the content of the work.

\section{Author's Contribution}

All authors contributed equally to this work.

\section{RESUMO}

No contexto da pandemia de COVID-19, o serviço de endoscopia deve adotar ações preventivas para manter seu funcionamento devido ao grande risco de contágio da doença. Protocolos de triagem antes e após o procedimento, equipamentos de proteção individual e controle de contaminação do ambiente fazem parte das recomendações das sociedades de endoscopia. Entretanto, o risco de infecção pode permanecer alto devido ao pouco controle da fonte de disseminação de contaminantes. A partir da combinação de suprimentos e de acessórios padronizados em um hospital, uma máscara de ventilação adaptada para ser usada em procedimentos endoscópicos é proposta com a finalidade de reduzir a contaminação por COVID-19.

PALAVRAS-CHAVE: Endoscopia. Endoscopia do sistema digestório. Equipamento de proteção individual. Dispositivos de proteção respiratória. Infecções por coronavírus. 


\section{REFERENCES}

1. Brasil. Gerência de Vigilância e Monitoramento em Serviços de Saúde, Gerência Geral de Tecnologia em Serviços de Saúde, Agência Nacional de Vigilância Sanitária. Nota técnica GVIMS/GGTES/ANVISA Nº 04/2020. Orientações para serviços de saúde: medidas de prevenção e controle que devem ser adotadas durante a assistência aos casos suspeitos ou confirmados de infecção pelo novo coronavírus (SARS-CoV-2). Brasília: Agência Nacional de Vigilância Sanitária; 2020. [cited 2020 May 8]. Available from: http://portal.anvisa.gov.br/documents/33852/271858/ Nota+T\%C3\%A9cnica+n+04-2020+GVIMS-GGTES-ANVISA/ ab598660-3de4-4f14-8e6f-b9341c196b28

2. Bai $Y$, Yao L, Wei T, Tian F, Jin DY, Chen L, et al. Presumed asymptomatic carrier transmission of COVID-19. JAMA. 2020;323(14):1406-7.

3. Galloro G, Pisani G, Zagari RM, Lamazza A, Cengia G, Ciliberto E, et al. Safety in digestive endoscopy procedures in the COVID era recommendations in progres of the Italian Society of Digestive Endoscopy. Dig Liver Dis. 2020;52(8):800-7.

4. World Health Organization. Rational use of personal protective equipment for coronavirus disease (COVID-19) and considerations during severe shortages. Geneva: World Health Organization; 2020. [cited 2020 May 8]. Available from: https://www.who.int/publications/i/item/ rational-use-of-personal-protective-equipment-for-coronavirus-disease-(COVID-19)-and-considerations-during-severe-shortages

5. Sociedade Brasileira de Endoscopia Digestiva. Medidas de prevenção: casos suspeitos ou confirmados. São Paulo: Sociedade Brasileira de Endoscopia Digestiva; 2020. [cited 2020 Jun 4]. Available from: https://www.sobed. org.br/fileadmin/user_upload/sobed/2020/04/01/COVID_-_protecao.pdf
6. Soetikno R, Teoh AYB, Kaltenbach T, Lau JYW, Asokkumar R, Cabral-Prodigalidad $\mathrm{P}$, et al. Considerations in performing endoscopy during the COVID19 pandemic. Gatrointest Endosc. 2020;92(1):176-83.

7. van Doremalen N, Bushmaker T, Morris DH, Holbrook MG, Gamble A, Williamson BN, et al. Aerosol and surface stability of SARS-CoV-2 as compared with SARS-CoV-1. N Engl J Med. 2020;382(16):1564-7.

8. Knowlton SD, Boles CL, Perencevich EN, Diekema DJ, Nonnenmann MW; CDC Epicenters Program. Bioaerosol concentrations generated from toilet flushing in a hospital-based patient care setting. Antimicrob Resist Infect Control. 2018;7:16.

9. Kähler C), Hain R. Flow analyses to validate SARS-CoV-2 protective masks. Neubiberg: University of the Bundeswehr Munich; 2020. [cited 2020 Jun 2]. Available from: https://www.unibw.de//rt7-en/report_mask-investigation_unibw_lrt7_06_04_2020.pdf

10. Bourouiba L, Dehandschoewercker E, Bush JW. Violent expiratory events: on coughing and sneezing. J Fluid Mech. 2014;745:537-63.

11. Viola IM, Peterson B, Pisetta G, Pavar G, Akhtar H, Menoloascina F, et al. Face coverings, aerosol dispersion and mitigation of virus transmission risk. Cornell University Medical Physics. [Online].; 2020. Available from: arXiv:2005.10720v1.

12. Marchese M, Capannolo A, Lombardi L, Di Carlo M, Marinangeli F, Fusco P. Use of a modified ventilation mask to avoid aerosolizing spread of droplets for short endoscopic procedures during coronavirus COVID-19 outbreak. Gastrointest Endosc. 2020;92(2):439-40. 